Review Article

\title{
The Relationship between Polymorphisms in the Vitamin D Receptor Gene and Bone Mineral Density in Postmenopausal Women
}

\author{
Jose M. Moran, ${ }^{1}$ Francisco J. Rodriguez-Velasco, ${ }^{1}$ Raul Roncero-Martin, ${ }^{1}$ \\ Purificación Rey-Sanchez, ${ }^{1}$ Mariana Martinez, ${ }^{1}$ and Juan D. Pedrera-Zamorano ${ }^{1,2}$ \\ ${ }^{1}$ Metabolic Bone Diseases Research Group, University of Extremadura, 10071 Cáceres, Spain \\ ${ }^{2}$ Departamento de Enfermería, Facultad de Enfermería y Terapia Ocupacional, Universidad de Extremadura, \\ Avenida Universidad s/n, 10071 Cáceres, Spain \\ Correspondence should be addressed to Juan D. Pedrera-Zamorano; jpedrera@unex.es
}

Received 3 October 2013; Accepted 8 December 2013; Published 9 January 2014

Academic Editors: P. A. Fasching and M. Nacak

Copyright (c) 2014 Jose M. Moran et al. This is an open access article distributed under the Creative Commons Attribution License, which permits unrestricted use, distribution, and reproduction in any medium, provided the original work is properly cited.

\begin{abstract}
The objective of this study was to identify, through a systematic review of the literature, Vitamin $\mathrm{D}$ receptor gene (VDR) polymorphisms related to osteoporosis and their effects on bone mineral density (BMD). The articles dated between January 2000 and December 2011 in the Scielo and PubMed databases were reviewed. A total of 23 articles that studied the association between the BsmI, ApaI, FokI, and TaqI polymorphisms and bone mineral density in postmenopausal women were selected. We found systematic studies/meta-analysis (level E-I) and case-control/cohort (level E-IV) studies. No definite conclusions can be made regarding the association of BsmI, ApaI, FokI, and TaqI polymorphisms with BMD among postmenopausal women. Larger and more rigorous analytical studies with consideration of gene-gene/environment interactions are needed to further dissect the mechanisms by which VDR alleles influence BMD.
\end{abstract}

\section{Introduction}

Osteoporosis is a systemic skeletal disease characterised by low bone mineral density (BMD) and the deterioration of the bone microarchitecture that leads to increased bone frailty and high-risk fractures [1]. It is the most common metabolic bone disease in the world, affecting one in three women and one in eight men over 50 years of age [2]. Postmenopausal osteoporosis is a major health problem due to its high prevalence and the large social health costs it incurs because of its clinical manifestations, specifically fractures. Approximately 200 million people worldwide suffer from this disease. The treatment of this disease has a direct annual cost of 54 billion dollars in Europe, the United States, and Canada alone, not including the additional ten million dollars in indirect costs. In Europe, the direct cost of this disease reached 48 billion Euros in the year 2000; the costs incurred solely in the hospitals have increased by $33 \%$ over the last three years.
In Spain, osteoporosis is the most prevalent metabolic bone disease.

Studies in twins $[3,4]$ and relatives $[5,6]$ estimate that genetic factors account for up to $50-90 \%$ of the total factors that determine bone mass [7-9] and contribute significantly to the following processes: peak bone mass acquisition $[4,5$, 10], turnover [11, 12], and loss of bone mass throughout the lifetime of the patient [13]. Four polymorphisms (BsmI, TaqI, ApaI, and FokI) in the Vitamin D receptor (VDR) gene have been studied more frequently because of their associations with BMD and osteoporosis. The VDR gene is located on the long arm of chromosome 12 (12q12.11) and is a member of the genetic receptor superfamily. The polymorphisms in the VDR gene were first postulated to predict the spinal and femoral BMD in Caucasian women in 1994 [14].

Although several studies on polymorphisms in the VDR gene have been published, the results have been contradictory, possibly because of variations in study design, small 
sample sizes, varying ethnic backgrounds, or environmental factors. The mechanism by which the VDR gene influences bone mass has not been fully elucidated [15]. The discrepancies in the results on the importance of this gene suggest that the control of bone mass is polygenic $[16,17]$. Based on the previous considerations, osteoporosis is considered a "complex" genetic trait, as it is multifactorial and multigenic. Genetic risk factors, certain alleles or genetic variants, are transmitted from one generation to the next. However, the phenotypic expression will depend on the interactions with other genetic variants and with environmental factors. It is necessary to investigate whether polymorphisms in the VDR gene may influence the pathogenesis of osteoporosis. It is essential to find a marker that identifies the women that will develop poor bone prognosis to facilitate early treatment for the prevention of the loss of bone mass. The identification of genetic markers that predict the risk of developing osteoporosis enables the prevention and treatment of this disease, which should be integrated into the development of nursing care plans.

\section{Methods}

An integrative literature review is one of the research methods used in evidence-based practice (EBP) that allows the incorporation of evidence into clinical practice. This method is designed to collect and synthesise the results of research on a specific, systematic, and methodical topic and deepens the knowledge on the research topic.

In the present study, the following classification for the levels of evidence [18] was used: (I) evidence generated from systematic reviews or meta-analysis of controlled trials or clinical practice guidelines established from evidence based on systematic reviews of randomised controlled trials, (II) evidence generated from at least one well-designed randomised clinical trial, (III) evidence obtained from well-designed controlled trials without randomization, (IV) evidence from well-designed studies on cases-controls and cohorts, (V) evidence from systematic reviews of qualitative and descriptive studies, (VI) evidence from only one qualitative or descriptive study, and (VII) evidence from the authorities or reports from expert committees. The development of this review followed previously described steps [19]. The PubMed (2000-2011) and Scielo (2000-2011) databases were mined. All genetic association studies investigating the relationship between the BsmI [rs1544410], ApaI [rs7975232], FokI [rs10735810], and TaqI [rs731236] polymorphisms and the VDR gene and osteoporosis development were considered in the integrative review. Combinations of the following words were used to identify studies: "VDR" or "Vitamin D Receptor" and "BMD" or "Bone Mineral Density." The search was restricted to articles published in English and Spanish. A total of 81 articles were initially identified in the databases, and the final sample integrated 23 articles. The articles were adjusted to the following inclusion criteria: (1) assessment the association between $V D R$ and BMD in postmenopausal women; (2) inclusion the number of subjects assigned to the sample and mean and standard deviation of the BMD for each $V D R$ genotype; and
(3) subjects without chronic diseases affecting BMD and no record of treatments affecting bone metabolism.

\section{Results}

The final sample contained 23 articles that studied the association between the BsmI, ApaI, FokI, and TaqI (VDR) polymorphisms and BMD; 2 articles focused on level E-I and 21 articles focused on level E-IV (13 case-control studies and 8 cohort studies). Based on the inclusion criteria outlined above, no articles were identified in the remaining levels. The articles included in this review were referenced with the following numbers: 17 and 20 to 41 .

3.1. BsmI . A total of 11 articles (2 articles in level E-I and 9 articles in level E-IV) were found that showed that the BsmI polymorphism affected the loss of BMD. In contrast, 4 articles reported that the BsmI polymorphism did not affect BMD; all of the articles were level E-IV (Table 1). There were 8 studies (2 articles in level E-I and 6 articles in level E-IV) supporting an association between the $B B$ genotype and $\mathrm{BMD}$; this was the largest amount of data supporting an association between a polymorphism and BMD. However, 4 articles reported no evidence that this polymorphism affected BMD. Furthermore, 2 studies on the genotype $B b$ showed an effect on BMD, as opposed to 4 studies that showed the same genotype had no effect on BMD (both in level E-IV). Two studies on the $b b$ genotype showed an effect on BMD, whereas 4 studies showed that no evidence of this effect (both in level E-IV).

3.2. ApaI. The effect of the ApaI polymorphism on BMD was analysed (Table 2 ). Four studies (1 article in level E-I and 3 articles in level E-IV) reported evidence of the effect of this polymorphism on BMD; in contrast, 2 studies showed no evidence of an effect (level E-IV). Likewise, 3 studies (1 article in level E-I and 2 articles in level E-IV) showed that the $A A$ genotype had an effect on BMD, whereas 2 articles showed no evidence of this effect (both in level E-IV). There was less evidence indicating an association between the aa genotype and BMD in level E-IV; 1 article showed an effect, but 3 articles showed no evidence of an affect. Three articles (level E-IV) showed no evidence that the $A a$ genotype affected BMD. There were no cohort studies that examined the effect of the ApaI polymorphism on BMD.

3.3. FokI. A total of 8 articles (level E-IV) studying the association of the FokI genotype with BMD were found; of the 8 articles, 6 articles reported evidence of an effect, but 2 articles showed no evidence of an effect on BMD (Table 3). There were several articles supporting the association between the ff genotype and BMD (6 articles showed an effect, whereas 2 articles did not find a relationship). We did not find any article that showed that the $F f$ and $F F$ polymorphisms affected $\mathrm{BMD}$. However, we found 2 articles rejecting such evidence (case-control studies).

3.4. TaqI . A total of 9 articles studying the effect of the TaqI polymorphism on BMD were found; 7 articles reported 
Table 1: Distribution of studies by the level of evidence and the effect of the BsmI polymorphism.

\begin{tabular}{|c|c|c|c|c|}
\hline \multirow{2}{*}{$\begin{array}{l}\text { Level of } \\
\text { evidence }\end{array}$} & & \multicolumn{3}{|c|}{ BsmI polymorphism } \\
\hline & & Genotype $b b$ & Genotype $B b$ & Genotype $B B$ \\
\hline E-I & & & & $\begin{array}{l}\text { Low values of BMD at femoral head } \\
{[20] \text { and low BMD values in spine }} \\
{[21] .}\end{array}$ \\
\hline \multirow[b]{2}{*}{ E-IV } & $C-C^{a}$ & $\begin{array}{l}\text { No influence on BMD values } \\
{[33,43-45], \text { low BMD values in }} \\
\text { forearm [22], and high incidence } \\
\text { of osteoporosis [23]. }\end{array}$ & $\begin{array}{c}\text { No influence on BMD values } \\
{[33,43-45] \text { and high incidence of }} \\
\text { osteoporosis [24]. }\end{array}$ & $\begin{array}{l}\text { No influence on BMD values } \\
{[33,43-45] \text { and high incidence of }} \\
\text { osteoporosis [24]. }\end{array}$ \\
\hline & $\mathrm{C}^{\mathrm{b}}$ & & $\begin{array}{l}\text { Low BMD values in trochanter } \\
\qquad[26] .\end{array}$ & $\begin{array}{c}\text { Low BMD values in spine }[27,28] \\
\text { low BMD levels in spine with low } \\
\text { calcium intake [29], and high } \\
\text { incidence of osteoporosis [30]. }\end{array}$ \\
\hline
\end{tabular}

${ }^{\mathrm{a}}$ Case-control; ${ }^{\mathrm{b}}$ cohort.

TABle 2: Distribution of studies by the level of evidence and the effect of the ApaI polymorphism.

\begin{tabular}{|c|c|c|c|c|}
\hline \multirow{2}{*}{$\begin{array}{l}\text { Level of } \\
\text { evidence }\end{array}$} & & \multicolumn{3}{|c|}{ ApaI polymorphism } \\
\hline & & Genotype $a a$ & Genotype Aa & Genotype $A A$ \\
\hline E-I & & & & Low BMD values in spine [21]. \\
\hline E-IV & $\mathrm{C}-\mathrm{C}^{\mathrm{a}}$ & $\begin{array}{l}\text { No influence on BMD values } \\
{[24,33,43] \text { and low BMD values }} \\
\text { in forearm [22]. }\end{array}$ & $\begin{array}{c}\text { No influence on BMD values } \\
\qquad[24,33,43] .\end{array}$ & $\begin{array}{c}\text { Weakly connected with } \\
\text { susceptibility to osteoporosis } \\
{[33,45] \text { and no influence on BMD }} \\
\text { values }[24,43] .\end{array}$ \\
\hline
\end{tabular}

${ }^{\mathrm{a}}$ Case-control; ${ }^{\mathrm{b}}$ cohort.

evidence of such an effect, whereas 2 articles did not show an effect. All of the articles were included in level E-IV. Several studies showed that the $t t$ genotype affected BMD; 3 of the articles showed an effect, whereas 2 studies did not show an effect (Table 4). The literature also supported an association between the TT genotype, the Tt genotype, and BMD. Two articles showed that the $T T$ genotype affected BMD, whereas 2 did not show an effect; all of the articles were case-control studies. One article showed that the Tt genotype had an effect on BMD, whereas 2 studies did not show an effect.

3.5. Interactions. Although some studies did not show evidence of an effect of the aforementioned polymorphisms on BMD, they did report an effect on their interactions. We observed that the haplotypes $A a B b$ and $B B A A t t$ and homozygote $b A T$ conferred an increased risk of osteoporosis (Table 5). They also conferred low BMD values for the femoral neck, whereas the haplotype BbaaTT conferred a protective effect. These studies were found in level E-IV.

\section{Discussion}

Osteoporosis is a disease with a genetic basis and an unknown aetiology. There is, however, evidence demonstrating the importance of age, lifestyle, gene interaction, and environmental conditions in the development of the disease [17]. Vitamin D plays an important role in calcium homeostasis, bone metabolism, and intestinal calcium absorption. VDR regulates the transcription of other genes (e.g., calcium-binding protein and osteocalcin) that are vital for calcium absorption and bone formation.

Our study uncovers scientific evidence in the literature (mainly in levels E-I and E-IV) that the BsmI polymorphism affected BMD. The polymorphism was associated with decreased BMD levels in each of the body areas studied (principally the femoral neck and spine), and there is an increased incidence of this genotype in patients with osteoporosis [20$30]$. In general it seems that a lower BMD was observed in the $B B$ homozygotes compared to heterozygotes [20], and there was an association between the homozygous $b b$ genotype and high BMD values $[29,30]$. In other studies in women, the $b b$ genotype has been associated with high calcium absorption in low calcium intake situations, compared to the $B B$ genotype [31]. With low calcium intake, the presence of the $B$ allele increased the risk of osteoporosis by $118 \%$. Meanwhile, the presence of the $t$ allele increased the risk of osteoporosis by $132 \%$ [29]. These associations remained constant even after adjusting for age, weight, and size. Smaller studies on samples from postmenopausal Caucasian women also confirmed the results regarding the effect of both the BsmI and TaqI polymorphisms [24]. The alleles of the VDR gene are hypothesised to function differently and contribute to the physiologically diverse levels of osteocalcin (the most abundant noncollagenous bone protein) because the expression of osteocalcin is induced by calcitriol through VDR [32]. The functional difference between the $V D R$ alleles caused by the presence of the polymorphism differentially regulated the transcriptional of the osteocalcin gene. Additionally, these polymorphisms have also been associated with bone remodelling; women with the 
TABLE 3: Distribution of studies by the level of evidence and the effect of the FokI polymorphism.

\begin{tabular}{|c|c|c|c|c|}
\hline \multirow{2}{*}{$\begin{array}{l}\text { Level of } \\
\text { evidence }\end{array}$} & & \multicolumn{3}{|c|}{ FokI polymorphism } \\
\hline & & Genotype $f f$ & Genotype $F f$ & Genotype FF \\
\hline \multirow[t]{2}{*}{ E-IV } & $C-C^{a}$ & $\begin{array}{l}\text { Low BMD values in spine [35]. } \\
\text { Lower values of BMD in hip, } \\
\text { after adjusting for age and body } \\
\text { mass index [33] and no influence } \\
\text { on BMD values }[24,43] .\end{array}$ & $\begin{array}{l}\text { No influence on BMD values } \\
\qquad[24,43] .\end{array}$ & $\begin{array}{c}\text { No influence on BMD values } \\
\qquad[24,43] .\end{array}$ \\
\hline & $C^{b}$ & $\begin{array}{c}\text { Low BMD values in spine } \\
{[36,37,39] . \text { High incidence of }} \\
\text { osteoporosis }[30,39] .\end{array}$ & & \\
\hline
\end{tabular}

${ }^{\mathrm{a}}$ Case-control; ${ }^{\mathrm{b}}$ cohort.

TABLE 4: Distribution of studies by the level of evidence and the effect of the TaqI polymorphism.

\begin{tabular}{|c|c|c|c|c|}
\hline \multirow{2}{*}{$\begin{array}{l}\text { Level of } \\
\text { evidence }\end{array}$} & & \multicolumn{3}{|c|}{ TaqI polymorphism } \\
\hline & & Genotype $t t$ & Genotype $T t$ & Genotype $T T$ \\
\hline \multirow{2}{*}{ E-IV } & $C-C^{a}$ & $\begin{array}{c}\text { Low BMD values in spine [38] } \\
\text { and no influence on BMD values } \\
{[33,43] .}\end{array}$ & $\begin{array}{l}\text { No influence on BMD values } \\
\qquad[33,43] .\end{array}$ & $\begin{array}{c}\text { High risk of osteoporosis in } \\
\text { postmenopausal women [34], low } \\
\text { BMD values in forearm [22], and no } \\
\text { influence on BMD values }[33,43] \text {. }\end{array}$ \\
\hline & $\mathrm{C}^{\mathrm{b}}$ & $\begin{array}{l}\text { Low BMD levels in spine with } \\
\text { low calcium intake [29] and high } \\
\text { incidence of osteoporosis [30]. }\end{array}$ & Low BMD values in spine [26]. & \\
\hline
\end{tabular}

${ }^{\mathrm{a}}$ Case-control; ${ }^{\mathrm{b}}$ cohort.

TABLE 5: Distribution of studies by the level of evidence and the related interactions within $V D R$ gene polymorphisms.

\begin{tabular}{|c|c|c|}
\hline $\begin{array}{l}\text { Level of } \\
\text { evidence }\end{array}$ & & $\begin{array}{l}\text { Interaction of haplotypes on the VDR } \\
\text { gene polymorphisms }\end{array}$ \\
\hline \multirow[t]{2}{*}{ E-IV } & $C-C^{a}$ & $\begin{array}{c}A a B b \text { confers an increased risk of } \\
\text { osteoporosis [17], BBAAtt confers a } \\
\text { higher risk of osteoporosis [41], and } \\
\text { BbaaTT confers a protective effect against } \\
\text { osteoporosis [41]. }\end{array}$ \\
\hline & $C^{b}$ & $\begin{array}{c}\text { bAT homozygote confers low BMD } \\
\text { values for the femoral head [36]. }\end{array}$ \\
\hline
\end{tabular}

${ }^{\mathrm{a}}$ Case-control; ${ }^{\mathrm{b}}$ cohort.

$B B$ genotype have reduced lumbar bone mass compared to those with the $b b$ genotype. Additionally, the women with the $B B$ genotype experienced accelerated bone remodelling with increased bone resorption, higher observed degradation of collagen type I, and increased calcitriol and phosphate values. These observed phenomena produce long-term mineral loss from the skeleton and low BMD.

There were fewer studies that met the inclusion criteria proposed in our study for the BsmI polymorphism compared to the ApaI polymorphism in levels E-I and E-IV. In general and particularly in a study positioned at level E-I, higher BMD was observed in the postmenopausal women who were $A a$ heterozygotes [20]. In contrast, lower BMD was observed in the individuals with the $A A$ genotype $[20,30]$. These results are similar to some previous studies in Finnish and Lebanese populations but are different from results reported in previous meta-analysis. There are several possible explanations for these differences: there are differences in allelic frequencies of the $B B$ and $A A$ genotypes, as there are much lower frequencies in Asians than in Caucasians according to HapMap, and ethnic differences may affect genetic susceptibility to the disease [20].

There are several studies on the FokI and TaqI polymorphisms, that prove the association between $V D R$ and BMD $[22,26,27,29,30,33-38]$. The data supporting this association were found to be in level E-IV, whereas none were identified in level E-I. The FokI polymorphism, resulting from a T/C transition in exon 2, created a new start codon (ATG) in the VDR gene. The changes in the DNA sequences encoding Vitamin D receptor proteins may indicate functional consequences; for example, the FokI polymorphism extends the protein by three amino acids and can affect the activity of Vitamin D3 receptor [33]. In most of the identified scientific studies, the ff genotype was associated with a lower BMD [30, 33,39 ] and a high prevalence of osteoporosis; the cause of the latter association is still under debate [33]. Some studies suggest the possibility that the FokI polymorphism influenced spongy bone tissue, which is more evident in the lumbar segment of the spine than in the neck of the femur [36]. Vitamin $\mathrm{D}$ has been used in antiresorptive therapies as the nonhypercalcemic analogues of 1,25-dihydroxyvitamin D. Vitamin $\mathrm{D}$ increased the response to estradiol levels and to the decrease in oestrogens used to treat osteoporosis in postmenopausal women. Thus, increases in bone mass after hormone replacement therapy were significantly associated with the TT genotype [40].

The associations of the different polymorphisms have also been studied. The haplotype BBAAtt has been described as a 
risk factor for osteoporosis; the haplotype BbaaTT has been described as a protective factor in Spanish populations [41]. The haplotype combination $A a B b$ conferred a fivefold greater risk when clinical parameters such as body mass index (BMI) were adjusted. Accordingly, studies suggest that candidate genes affecting metabolic parameters as well as BMI can alter the risk of osteoporosis [17]. An investigation of 75 analysed studies on VDR gene polymorphisms and BMD concluded that these polymorphisms were significantly associated with BMD. Additionally, the investigation concluded that the genotypic effect was more prominent in premenopausal women than in postmenopausal women [42].

The VDR gene regulates the transcription of target genes (e.g., calcium-binding protein and osteocalcin) that are crucial for calcium absorption and bone formation. The mechanism by which the $V D R$ gene affects BMD remains unknown. In addition, polymorphisms in the $V D R$ gene and other genes and pathways, such as the oestrogen signalling pathway, Wnt/ $\beta$-catenin, transforming growth factor superfamily, and the activating receptor of the nuclear factor $\kappa \mathrm{B}$ (RANK) signalling pathway, can affect BMD and regulate the effect of the $V D R$ gene polymorphisms on BMD. One of the current and most probable reasons might be varying hormone levels, which can influence the effect of the VDR gene polymorphisms on BMD.

In addition, environmental factors such as diet, physical activity, smoking, and alcohol consumption have been proven to influence BMD and osteoporosis. Therefore, these gene-environment factors may act as confusing elements that affect the association between VDR polymorphisms and BMD [20]. However, different genotypes may also have diverse effects on different parts of the skeleton. This might explain why several studies did not find an association between $V D R$ polymorphisms and BMD [26].

This study has several limitations because it was performed on a limited sample of studies on postmenopausal women. Hence, our findings cannot be generalised to specific populations, geographic locations, or different age subgroups. Parallel research on large-scale familial studies of postmenopausal women and younger individuals can help to clarify the exact role of genetic markers (including VRD alleles) on bone mass loss.

\section{Conclusion}

From our comprehensive survey of the current available literature it can be concluded that $V D R$ polymorphisms do not appear to directly confer any significant BMD benefit. Indeed, no definite conclusions can be made regarding the association of BsmI, ApaI, FokI, and TaqI polymorphism with BMD among postmenopausal women. These findings show the importance of establishing suitable criteria, including genetic epidemiologic, phenotypic, and clinical criteria, to improve quality control of study design and methods in genetic studies related to VDR gene polymorphism and BMD. Based on these criteria, larger and more rigorous analytical studies with consideration of gene-gene/environment interactions are needed to further dissect the mechanisms by which $V D R$ alleles influ- ence BMD and interact with the other genetic and environmental factors.

\section{Conflict of Interests}

The authors declare that there is no conflict of interests regarding the publication of this paper.

\section{References}

[1] W. A. Peck, P. Burckhardt, C. Christiansen et al., "Consensus development conference: diagnosis, prophylaxis, and treatment of osteoporosis," American Journal of Medicine, vol. 94, no. 6, pp. 646-650, 1993.

[2] W.-F. Li, S.-X. Hou, B. Yu, M.-M. Li, C. Férec, and J.-M. Chen, "Genetics of osteoporosis: accelerating pace in gene identification and validation," Human Genetics, vol. 127, no. 3, pp. 249$285,2010$.

[3] J. C. Christian, P.-L. Yu, C. W. Slemenda, and C. C. Johnston Jr., "Heritability of bone mass: a longitudinal study in aging male twins," American Journal of Human Genetics, vol. 44, no. 3, pp. 429-433, 1989.

[4] N. A. Pocock, J. A. Eisman, J. L. Hopper, M. G. Yeates, P. N. Sambrook, and S. Eberl, "Genetic determinants of bone mass in adults. A twin study," Journal of Clinical Investigation, vol. 80, no. 3, pp. 706-710, 1987.

[5] E. Seeman, J. L. Hopper, L. A. Bach et al., "Reduced bone mass in daughters of women with osteoporosis," The New England Journal of Medicine, vol. 320, no. 9, pp. 554-558, 1989.

[6] F. A. Tylavsky, A. D. Bortz, R. L. Hancock, and J. J. Anderson, "Familial resemblance of radial bone mass between premenopausal mothers and their college-age daughters," Calcified Tissue International, vol. 45, no. 5, pp. 265-272, 1989.

[7] J. A. Eisman, "Vitamin D receptor gene alleles and osteoporosis: an affirmative view," Journal of Bone and Mineral Research, vol. 10, no. 9, pp. 1289-1293, 1995.

[8] J. A. Eisman, N. A. Morrison, P. J. Kelly et al., "Genetics of osteoporosis and vitamin D receptor alleles," Calcified Tissue International, vol. 56, supplement 1, pp. S48-S49, 1995.

[9] S. H. Ralston and B. de Crombrugghe, "Genetic regulation of bone mass and susceptibility to osteoporosis," Genes and Development, vol. 20, no. 18, pp. 2492-2506, 2006.

[10] R. A. Evans, G. M. Marel, E. K. Lancaster, S. Kos, M. Evans, and S. Y. Wong, "Bone mass is low in relatives of osteoporotic patients," Annals of Internal Medicine, vol. 109, no. 11, pp. 870873, 1988.

[11] P. J. Kelly, J. L. Hopper, G. T. Macaskill, N. A. Pocock, P. N. Sambrook, and J. A. Eisman, "Genetic factors in bone turnover," Journal of Clinical Endocrinology and Metabolism, vol. 72, no. 4, pp. 808-813, 1991.

[12] A. Tokita, P. J. Kelly, T. V. Nguyen et al., "Genetic influences on type I collagen synthesis and degradation: further evidence for genetic regulation of bone turnover," Journal of Clinical Endocrinology and Metabolism, vol. 78, no. 6, pp. 1461-1466, 1994.

[13] L. Flicker, J. L. Hopper, L. Rodgers, B. Kaymakci, R. M. Green, and J. D. Wark, "Bone density determinants in elderly women: a twin study," Journal of Bone and Mineral Research, vol. 10, no. 11, pp. 1607-1613, 1995.

[14] N. A. Morrison, J. C. Qi, A. Tokita et al., "Prediction of bone density from vitamin D receptor alleles," Nature, vol. 367, no. 6460, pp. 284-287, 1994. 
[15] J. P. Ioannidis, I. Stavrou, T. A. Trikalinos et al., "Association of polymorphisms of the estrogen receptor $\alpha$ gene with bone mineral density and fracture risk in women: a meta-analysis," Journal of Bone and Mineral Research, vol. 17, no. 11, pp. 2048-2060, 2002.

[16] A. G. Uitterlinden, Y. Fang, J. B. Van Meurs, H. A. Pols, and J. P. Van Leeuwen, "Genetics and biology of vitamin D receptor polymorphisms," Gene, vol. 338, no. 2, pp. 143-156, 2004.

[17] T. M. Durusu, T. G. Bora, T. D. Uluturk et al., "Evaluation of the effects of vitamin D receptor and estrogen receptor 1 gene polymorphisms on bone mineral density in postmenopausal women," Clinical Rheumatology, vol. 29, no. 11, pp. 1285-1293, 2010.

[18] B. M. Melnyk and E. Fineout-Overholt, Evidence-Based Practice in Nursing and Healthcare a Guide to Best Practice, Lippincott Williams \& Wilkins, Philadelphia, Pa, USA, 2005.

[19] R. Whittemore and K. Knafl, "The integrative review: updated methodology," Journal of Advanced Nursing, vol. 52, no. 5, pp. 546-553, 2005.

[20] Y. Li, B. Xi, K. Li, and C. Wang, "Association between vitamin D receptor gene polymorphisms and bone mineral density in Chinese women," Molecular Biology Reports, vol. 39, no. 5, pp. 5709-5717, 2012.

[21] A. Thakkinstian, C. D’Este, J. Eisman, T. Nguyen, and J. Attia, "Meta-analysis of molecular association studies: vitamin D receptor gene polymorphisms and BMD as a case study," Journal of Bone and Mineral Research, vol. 19, no. 3, pp. 419-428, 2004.

[22] K. Douroudis, K. Tarassi, G. Ioannidis et al., "Association of vitamin $\mathrm{D}$ receptor gene polymorphisms with bone mineral density in postmenopausal women of Hellenic origin," Maturitas, vol. 45, no. 3, pp. 191-197, 2003.

[23] R. Lisker, M. A. López, S. Jasqui et al., "Association of vitamin D receptor polymorphisms with osteoporosis in Mexican postmenopausal women," Human Biology, vol. 75, no. 3, pp. 399403, 2003.

[24] B. L. Langdahl, C. H. Gravholt, K. Brixen, and E. F. Eriksen, "Polymorphisms in the vitamin D receptor gene and bone mass, bone turnover and osteoporotic fractures," European Journal of Clinical Investigation, vol. 30, no. 7, pp. 608-617, 2000.

[25] L. Borjas-Fajardo, M. Zambrano, E. Fernández et al., "Analysis of Bsm I polymorphism of the vitamin D receptor (VDR) gene in Venezuelan female patients living in the state of Zulia with osteoporosis," Investigacion Clinica, vol. 44, no. 4, pp. 275-282, 2003 (Spanish).

[26] J. G. Kim, J. H. Kwon, S. H. Kim, Y. M. Choi, S. Y. Moon, and J. Y. Lee, "Association between vitamin D receptor gene haplotypes and bone mass in postmenopausal Korean women," American Journal of Obstetrics and Gynecology, vol. 189, no. 5, pp. 12341240, 2003.

[27] H. Y. Chen, W. C. Chen, C. D. Hsu, F. J. Tsai, C. H. Tsai, and C. W. Li, "Relation of BsmI vitamin D receptor gene polymorphism to bone mineral density and occurrence of osteoporosis in postmenopausal Chinese women in Taiwan," Osteoporosis International, vol. 12, no. 12, pp. 1036-1041, 2001.

[28] J. Marc, J. Preželj, R. Komel, and A. Kocijančič, "Association of vitamin D receptor gene polymorphism with bone mineral density in Slovenian postmenopausal women," Gynecological Endocrinology, vol. 14, no. 1, pp. 60-64, 2000.

[29] M. G. Stathopoulou, G. V. Z. Dedoussis, G. Trovas et al., "The role of vitamin $\mathrm{D}$ receptor gene polymorphisms in the bone mineral density of Greek postmenopausal women with low cal- cium intake," Journal of Nutritional Biochemistry, vol. 22, no. 8, pp. 752-757, 2011.

[30] S. Mitra, M. Desai, and K.-H. M. Ikram, "Vitamin D receptor gene polymorphisms and bone mineral density in postmenopausal Indian women," Maturitas, vol. 55, no. 1, pp. 27-35, 2006.

[31] B. Dawson-Hughes, S. S. Harris, and S. Finneran, "Calcium absorption on high and low calcium intakes in relation to vitamin D receptor genotype," Journal of Clinical Endocrinology and Metabolism, vol. 80, no. 12, pp. 3657-3661, 1995.

[32] N. A. Morrison, R. Yeoman, P. J. Kelly, and J. A. Eisman, “Contribution of trans-acting factor alleles to normal physiological variability: vitamin D receptor gene polymorphisms and circulating osteocalcin," Proceedings of the National Academy of Sciences of the United States of America, vol. 89, no. 15, pp. 66656669, 1992.

[33] K. Zajíčková, I. Žofková, R. Bahbough, and A. Křepelová, "Vitamin $\mathrm{D}$ receptor gene polymorphisms, bone mineral density and bone turnover: FokI genotype is related to postmenopausal bone mass," Physiological Research, vol. 51, no. 5, pp. 501-509, 2002.

[34] A. Seremak-Mrozikiewicz, K. Drews, P. M. Mrozikiewicz et al., "Correlation of vitamin D receptor gene (VDR) polymorphism with osteoporotic changes in Polish postmenopausal women," Neuroendocrinology Letters, vol. 30, no. 4, pp. 540-546, 2009.

[35] A. Falchetti, C. Sferrazza, C. Cepollaro et al., "FokI polymorphism of the vitamin $\mathrm{D}$ receptor gene correlates with parameters of bone mass and turnover in a female population of the Italian island of Lampedusa," Calcified Tissue International, vol. 80, no. 1, pp. 15-20, 2007.

[36] W. Horst-Sikorska, R. Kalak, A. Wawrzyniak, M. Marcinkowska, L. Celczynska-Bajew, and R. Slomski, "Association analysis of the polymorphisms of the VDR gene with bone mineral density and the occurrence of fractures," Journal of Bone and Mineral Metabolism, vol. 25, no. 5, pp. 310-319, 2007.

[37] E. Bandrés, I. Pombo, M. González-Huarriz, A. Rebollo, G. López, and J. García-Foncillas, "Association between bone mineral density and polymorphisms of the VDR, ERalpha, COL1A1 and CTR genes in Spanish postmenopausal women," Journal of Endocrinological Investigation, vol. 28, no. 4, pp. 312-321, 2005.

[38] B. S. Duman, R. Tanakol, N. Erensoy, M. Öztürk, and S. Yilmazer, "Vitamin D receptor alleles, bone mineral density and turnover in postmenopausal osteoporotic and healthy women," Medical Principles and Practice, vol. 13, no. 5, pp. 260-266, 2004.

[39] H.-Y. Chen, W.-C. Chen, C.-D. Hsu, F.-J. Tsai, and C.-H. Tsai, "Relation of vitamin D receptor FokI start codon polymorphism to bone mineral density and occurrence of osteoporosis in postmenopausal women in Taiwan," Acta Obstetricia et Gynecologica Scandinavica, vol. 81, no. 2, pp. 93-98, 2002.

[40] T. Kurabayashi, H. Matsushita, M. Tomita et al., "Association of vitamin $\mathrm{D}$ and estrogen receptor gene polymorphism with the effects of longterm hormone replacement therapy on bone mineral density," Journal of Bone and Mineral Metabolism, vol. 22, no. 3, pp. 241-247, 2004.

[41] M. Zambrano-Morales, L. Borjas, E. Fernández et al., "Association of the vitamin D receptor gene BBAAtt haplotype with osteoporosis in post-menopausic women," Investigación Clinica, vol. 49, no. 1, pp. 29-38, 2008 (Spanish).

[42] G. Gong, H. S. Stern, S.-C. Cheng et al., "The association of bone mineral density with vitamin D receptor gene polymorphisms," Osteoporosis International, vol. 9, no. 1, pp. 55-64, 1999. 
[43] T. Yoldemir, D. G. Yavuz, G. Anik, N. Verimli, and M. Erenus, "Vitamin D receptor gene polymorphisms in a group of postmenopausal Turkish women: association with bone mineral density," Climacteric, vol. 14, no. 3, pp. 384-391, 2011.

[44] S. Valimaki, R. Tahtela, K. Kainulainen et al., "Relation of collagen type I alpha 1 (COLIA 1) and vitamin D receptor genotypes to bone mass, turnover, and fractures in early postmenopausal women and to hip fractures in elderly people," European Journal of Internal Medicine, vol. 12, no. 1, pp. 48-56, 2001.

[45] G. R. Fontova, F. C. Gutiérrez, M. M. Broch et al., "Polymorphism of vitamin D receptor gene, bone mass, and bone turnover among women with postmenopausal osteoporosis," Revista Clinica Española, vol. 200, no. 4, pp. 198-202, 2000 (Spanish). 

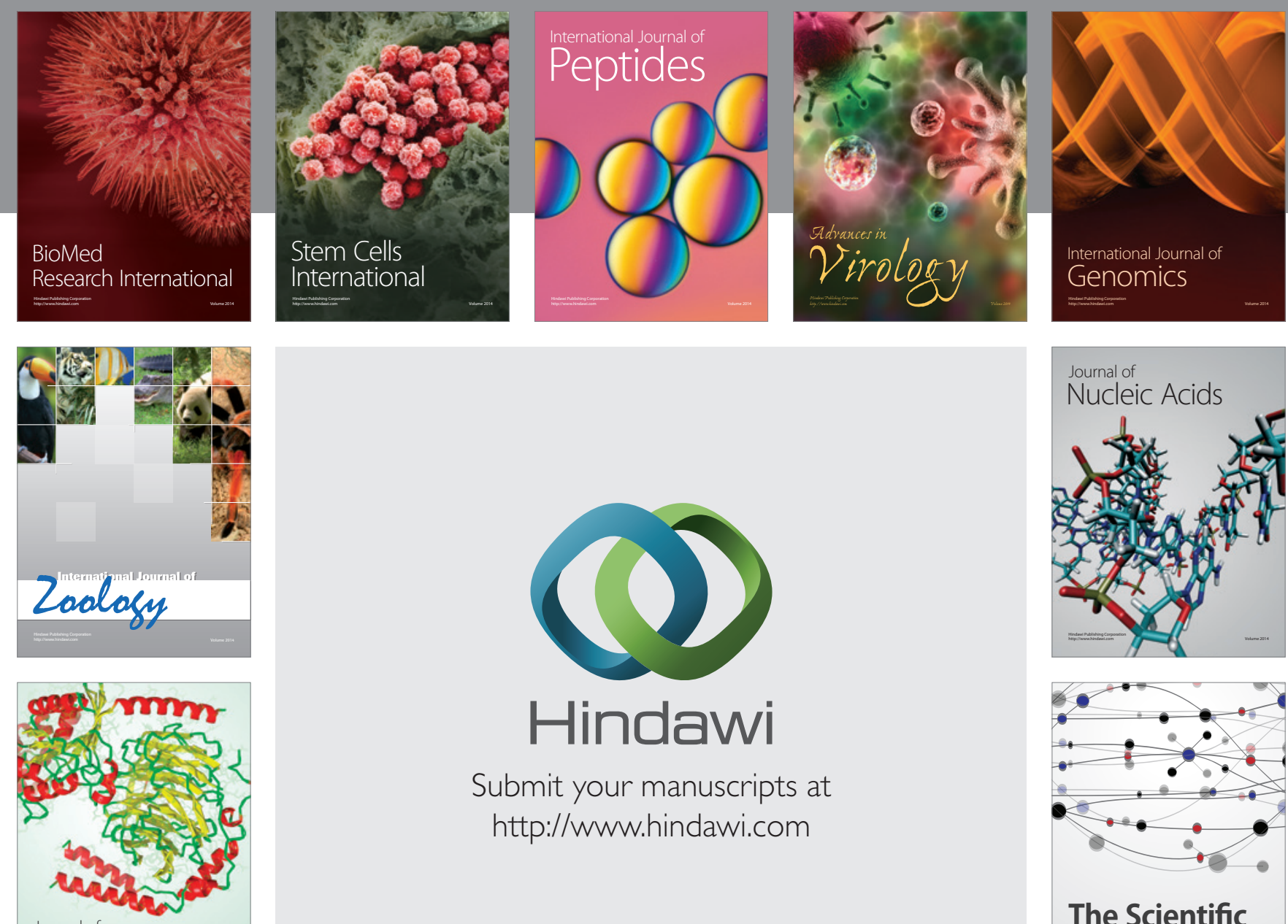

Submit your manuscripts at

http://www.hindawi.com

Journal of
Signal Transduction
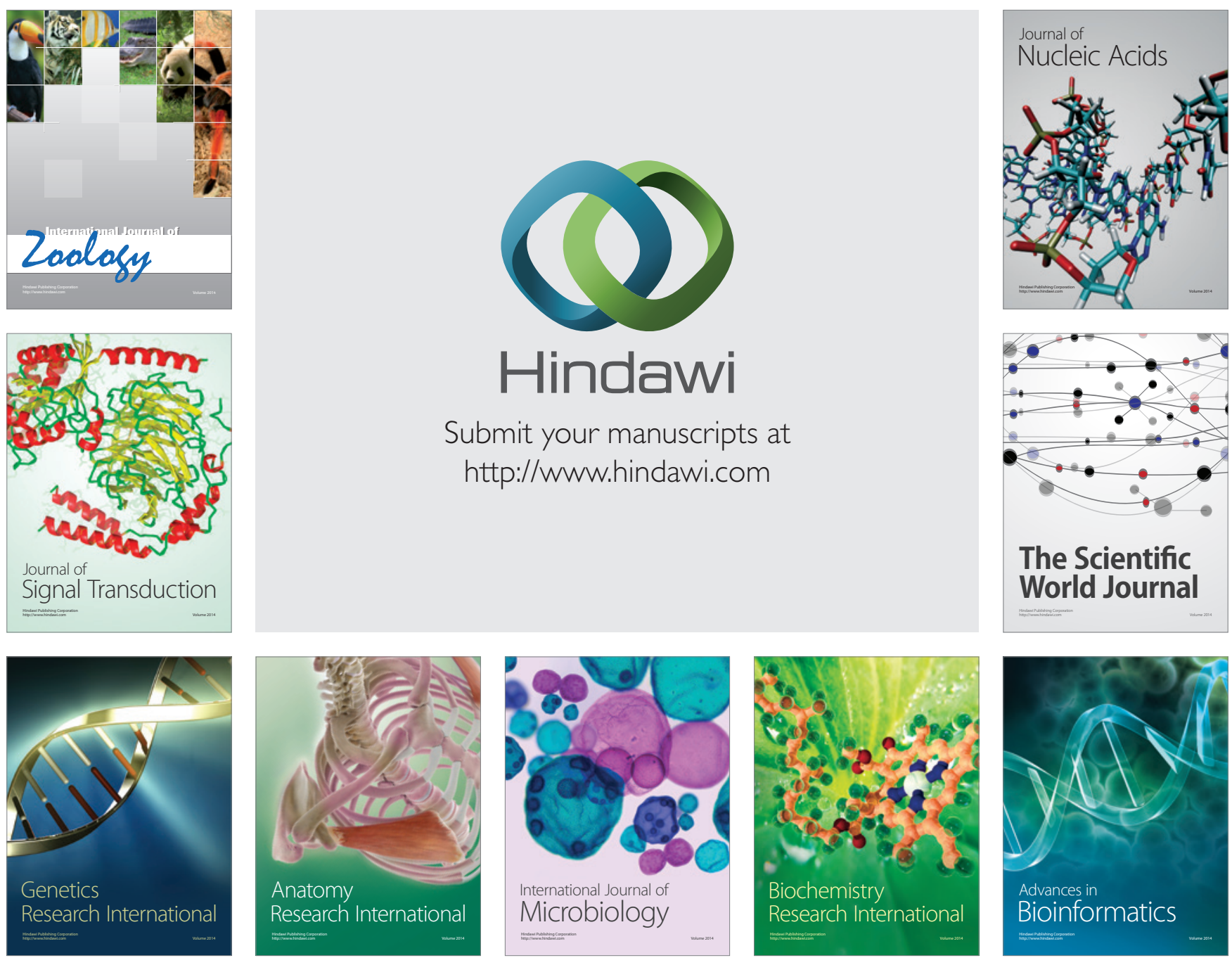

The Scientific World Journal
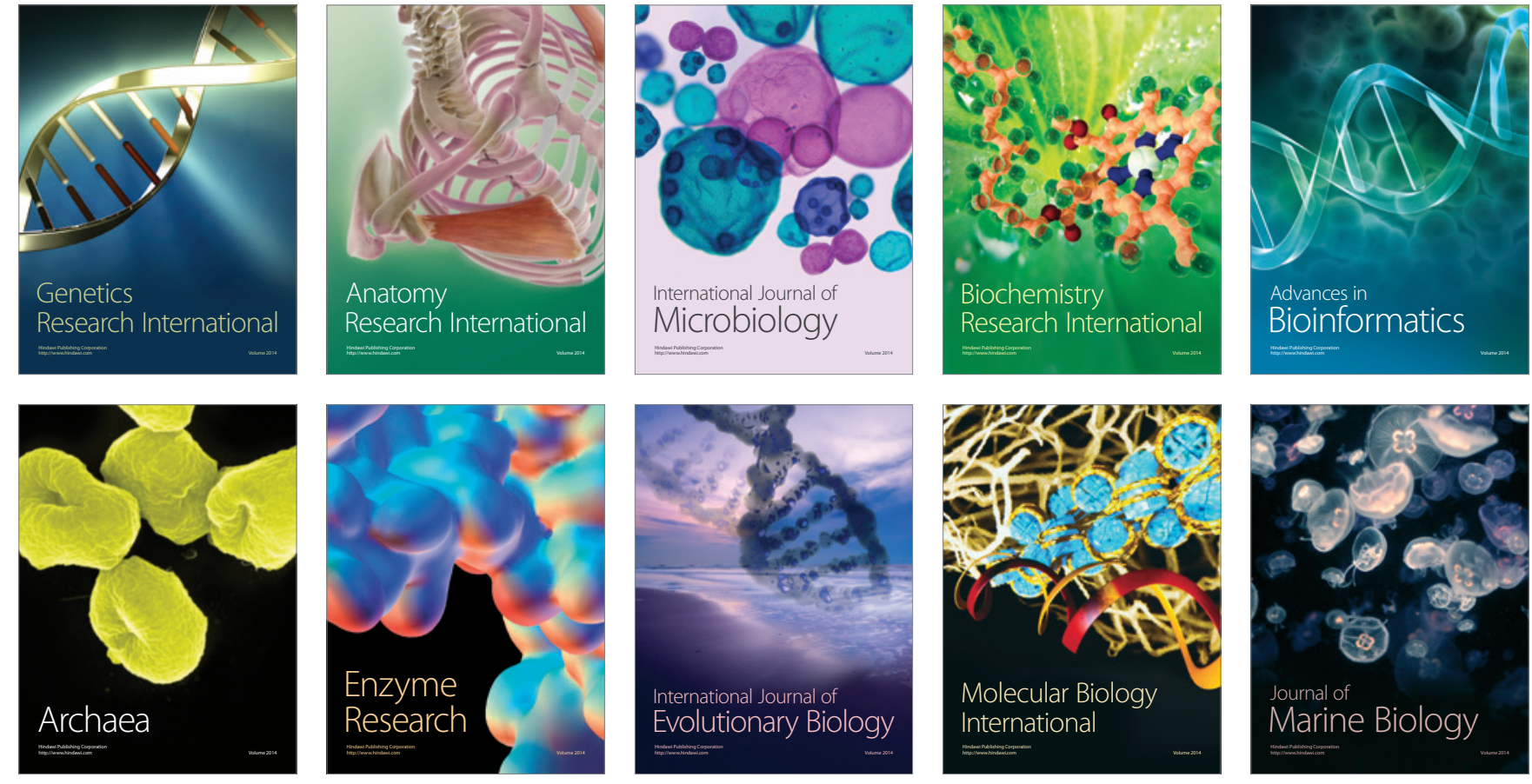